\title{
CRIMINAL SANCTIONS AND ACTIONS IN RELIGIOUS JUSTICE CRIME LAW ENFORCEMENT
}

\author{
Carto Nuryanto \\ Central Java Police \\ cartonuryanto@gmail.com
}

\begin{abstract}
Victims of drug abuse in the mandate of the Act should the victim run a rehabilitation, will remain in reality the victim immediately subjected to criminal penalties, so that there is a non-compliance with the law enforcement system carried out by the authorities with statutory regulations, weaknesses in the criminal sanction policy and actions in law enforcement in handling the current drug crime, as well as how the reconstruction of criminal sanctions policies and actions in the enforcement of the drug crime control system in realizing religious justice.
\end{abstract}

\section{Keywords: Crime law enforcement, Criminal Sanctions, Religious Justice}

\section{A. INTRODUCTION}

Act of No. 35/2009 concerning Narcotics in fact has a spirit or spirit to save drug abusers. Particularly implied in Article 4 letter b it is clearly stated that this Law aims to prevent, protect and save the Indonesian people from abuse of Narcotics. While in letter $d$ it also states that this Law guarantees the regulation of medical and social rehabilitation efforts for narcotics abusers and addicts. ${ }^{1}$.

As for the improvement, control and supervision as an effort to prevent and eradicate drug abuse and illicit trafficking, it is very necessary because narcotics crimes are generally not committed by individuals individually, but rather are carried out jointly even carried out by organized and secret syndicates. In addition, narcotics crimes are transnational in nature using the modus operandi and sophisticated technology, including securing the results of narcotics crimes. While the development of the quality of narcotics crime has become a very serious threat to the lives of humanity. Accordingly, Law No. 22 of 1997 concerning narcotics which is expected to be more effective in preventing and combating the abuse and illicit trafficking of narcotics in the territory of the Republic of Indonesia.

Narcotics, psychotropic substances and other addictive substances are the abbreviation of narcotics, which are chemicals that are asked to enter the human body in various ways, inhaled, inhaled, drunk or injected, can be used in accordance with desire, dialogue, and action. ${ }^{2}$

In order to give a psychological effect to the public so that they do not commit narcotics crime, it is necessary to stipulate a heavier, minimum and maximum criminal threat, considering

1 Samosir, Djisman, FUNGSI PIDANA PENJARA DALAM SISTEM PEMIDANAAN DI INDONESIA, Bina Cipta, Bandung, 1992, P.67.

2 Maydiya Restacendi Nur'artavia, KARAKTERISTIK PELAJAR PENYALAHGUNA NAPZA DAN JENIS NAPZA YANG DIGUNAKAN DI KOTA SURABAYA, The Indonesian Journal of Public Health, Vol. 12 No. 1, Juli 2017: P.27-38 
the level of danger posed by narcotics abuse and distribution greatly threatens national security resilience.

To better ensure the effectiveness of the implementation of control and supervision as well as the prevention and eradication of narcotics abuse and illicit trafficking, it is necessary to establish a national-level coordinating body in the field of narcotics while still seriously considering the various provisions of the applicable laws and regulations.

Then in its development, Law No. 22 of 1997 concerning Narcotics replaced with Law No. 35 of 2009 concerning narcotics, which is based on the reason that narcotics are substances or drugs that are very useful and necessary for the treatment of certain diseases. However, if abused or used not in accordance with the standards of treatment can have very detrimental consequences for individuals or communities, especially the younger generation. This will be more detrimental if accompanied by abuse and illicit trafficking of narcotics which can result in greater danger to the lives and cultural values of the nation which will ultimately weaken national security.

To prevent and eradicate the abuse and illicit trafficking of Narcotics which is very detrimental and endangering the lives of the people, nation and state, and at the General Session of the People's Consultative Assembly of the Republic of Indonesia in 2002 through the Decree of the People's Consultative Assembly of the Republic of Indonesia Number VI / MPR / 2002 has recommended it to the Council of the People's Consultative Assembly of the Republic of Indonesia in 2002 The People's Representative of the Republic of Indonesia and the President of the Republic of Indonesia to amend Law Number 22 of 1997 concerning Narcotics.

In Act No. 35 of 2009 as a penal to combat narcotic crime, narcotics offenses set on problems, which are more fully described in Chapter XV of the Criminal Provisions consisting of 38 in the same chapter, such as the Criminal Code. In Act No. 35 of 2009, the narcotics are divided into class I, class II, and class III. Group I considered more dangerous than class II and class III. Similarly, the class II are seen as more dangerous than class III, so that the criminal threat stratified according to the class. ${ }^{3}$

Narcotics misuse as the use of narcotics by someone illegally or against the law, that is without the knowledge and supervision of a doctor. Therefore, the prevention and eradication of drug abuse and illicit trafficking continues to be activated by the National Narcotics Agency (BNN). Various methods are used by the government, law enforcement and anti-drug social organizations to suppress or even eliminate the circulation and abuse of narcotics in Indonesia. One of them is by socializing about the dangers of narcotics. In addition, rehabilitation efforts are also a step to reduce the magnitude of narcotics abuse in Indonesia.

Law enforcement officials tend to impose criminal sanctions for the perpetrators of these crimes, without carrying out rehabilitation. By providing criminal sanctions in the form of imprisonment, it is expected that the perpetrators of criminal acts of narcotics abuse become deterrent and not repeat their actions. But what happens is the opposite, criminal sanctions in the form of imprisonment are not effective in making them deterrent from using narcotics. Without the detoxification process through the medical rehabilitation process, they will immediately go back to look for narcotics once they leave prison.

3 Andri winjaya laksana, Arpangi, JURIDICAL ANALYSIS OF SANCTIONS TRESPASSER AGAINST NARCOTIC'S VICTIM BASED ON UTILITARIANISM JUSTICE VALUES, Jurnal Pembaharuan Hukum, Volume VI No.1 Januari-April, P.135-145. 
Act of No. 35 of 2009 concerning Narcotics mandates law enforcement, especially investigators and public prosecutors to protect, save and guarantee drug abusers are rehabilitated. However, more than $90 \%$ of defendants who use narcotics have been accused by investigators as perpetrators of crime rather than victims and have been charged with alternative or indictment or cumulative charges in the judicial process.

Referring to the problem, it is impossible for investigators and prosecutors to carry out the mandate and purpose of making Law Number 35 of 2009 concerning Narcotics. It is also impossible for investigators and prosecutors to have the spirit to guarantee that abusers are rehabilitated (Article 4d).

Article 4 of Law Number 35 Year 2009 concerning Narcotics states that law enforcers, especially prosecutors are given the mandate to guarantee rehabilitation of abusers through a single indictment. In addition, prosecutors do not detain during the prosecution of cases of possession or cases of narcotics abuse in a certain amount for the benefit of a day to use, for themselves and not for sale.

This is where the rehabilitative spirit of enforcement must be owned by investigators, public prosecutors, and judges as well as the community because the abusers, especially victims are guaranteed that the Law to be rehabilitated is not even imprisoned.

The role of prosecutors in the rehabilitation justice system is also very strategic for abusing cases through a single indictment because the aim is to protect and save (Article 4b). Then the case of narcotics abuse for themselves (Article 127) and guaranteeing the abuser is rehabilitated (article 4d). The reason is that the abuser for himself does not meet the requirements if the defendant's status is detained (Article 21 of the Criminal Procedure Code).

This single indictment is a mandate from the purpose of the Narcotics Law. Therefore the prosecutor must sort out where the crime of circulation, which is a crime of abuse, including where the user who is concurrently a dealer and which is the user who has become an addict. The crime of misuse for oneself, not for sale must be protected, rescued (Article 4b), and must be guaranteed to get rehabilitation (Article 4d). Whereas dealers must be eradicated (Article 4c).

If the investigator still suspects the abuser as a criminal offender who deserves to be detained and the public prosecutor is indicting in the form of an alternative indictment, subsidair and cumulative indictment, then there is a gap to detain the abuser. This gap is still happening today. As a result, the abuser loses his right to be rehabilitated and recovered and the victim continues to be an abuser during and after serving his sentence, even worse while in prison due to being influenced by other prisoners. This would be a burden on the state.

Almost all the indictments dropped by the abusers are not a single indictment but an alternative, criminal and cumulative indictment accompanied by detention from the time of investigation, prosecution to trial. That is why abusers in the law enforcement process experience detention and end up in prison and don't be surprised if prison in Indonesia is overloaded.

Concerning the prosecutor's duty as a researcher as a result of investigating narcotics crimes, especially against abuser cases, based on Law Number 35 of 2009 concerning narcotics the preparation of the indictments is excluded from the criminal justice system, adjusted for the purpose of making the Act. The public prosecutor must be extra careful because the abuser is a criminal case whose defendant is guaranteed by law to be rehabilitated (Article 4c). Abuse cases which by Law Number 35 Year 2009 concerning narcotics are decriminalized (acts which initially considered criminal, then considered as normal behavior). This means that the process follows the 
criminal justice system, the defendant is threatened with crime (Article 127). Forced efforts in the form of rehabilitation (Article 13 PP 25/2011), sanctions in the form of rehabilitation punishment (Article 103/1).

Decriminalization of narcotics abusers is indeed difficult to understand by the community and law enforcement because it is not well socialized and not taught in law schools in Indonesia. That is because only criminal justice systems are taught. As a result, when Law Number 35 of 2009 embraced the rehabilitation justice system by decriminalizing drug abuse, many people and law enforcers stuttered because their mindset was still a criminal justice system. Cases of abusers are still looking for ways to be detained and sentenced to prison until now even though the Narcotics Law has been running for 9 years.

In the future the task of prosecutors is tougher, namely: Building a single indictment in accordance with the mandate of the Narcotics Act, building synergy with investigators to unite the steps so that the abuser gets a rehabilitation sentence from the judge who adjudicates despite being charged with a criminal threat. Furthermore, the prosecutor is also tasked with ensuring the abuser gets rehabilitation to recover from addiction in order to carry out his social obligations. In addition, the prosecutor also coordinates with relevant agencies that carry out the rehabilitation function as a compulsory rehabilitation site from law enforcement sources.

If compulsory rehabilitation from law enforcement sources is carried out well, rehabilitation will flourish compulsory rehabilitation according to Article 55 of the Narcotics Law and PP 25 of 2011 concerning Obligatory Reporting Addicts. And furthermore, it is very possible to grow an "independent" rehabilitation movement by parents / families whose children become abusers without fear anymore dealing with law enforcement because of clear forced efforts and punishment in the form of rehabilitation.

To follow up on the command of Law No. 35 of 2009 concerning Narcotics, a joint regulation has been made between seven state institutions regarding the technical implementation of rehabilitation of narcotics abusers. The regulation was signed by the Chief Justice of the Supreme Court, the Minister of Law and Human Rights, the Minister of Health, the Minister of Social Affairs, the Attorney General, the Head of the Indonesian National Police, the Head of the National Narcotics Agency. The regulation was set on March 11, 2014. If you look at the time span between Law No. 35 of 2009 concerning Narcotics made in 2009 and the joint regulations of the seven state institutions regarding the implementation of rehabilitation techniques that were made new in 2014, then the question big is how the technical implementation of the rehabilitation before the emergence of a joint regulation of seven state institutions, or the more fundamental question is whether so far law enforcement officials have carried out the mandate contained in Article 54 of Law No.35 Year 2009. Because so far the tendency of law enforcement officers in handling cases of narcotics abuse is to impose criminal sanctions alone without imposing rehabilitation sanctions, of course this is the opposite of what is contained and listed in Article 54 of Law No.35 Year 2009.

\section{B. DISCUSSION}

Act Number 35 of 2009 is a public law, because in Act Number 35 of 2009 regulates the interests of the general public and involves the government as a supervisor of the enactment of the Act. Law Number 35 Year 2009 is included in criminal law, which is the law governing all provisions regarding narcotics and there are criminal sanctions for those who violate the Act, so 
that in an effort to combat narcotics crime, Act Number 35 The year 2009 must be upheld regardless of the position or social status of the criminal.

From this we can analyze that the majority of prisoners who were convicted of criminal sanctions were non-drug users (victims), but they were imprisoned on the grounds that they had abused narcotics attributed to investigators under Article 127 of Law Number 35 Year 2009 of Tetang Narcotics. Whereas this law implies the mandate of rehabilitation both medical and social in order to save victims from the bondage of narcotics. This shows that there is something wrong with our law, either because of the ambiguity of the article clauses in the law, the law enforcement system or precisely with the law enforcers themselves. Keep in mind the aim is to create justice as fairly as possible rather than blindly and equate everyone without seeing the cause.

In the religious/religious level, justice is defined as the granting of the rights he should receive based on the degree of effect of the act that he deserves according to God's command. Islam commands every human being to do justice or uphold justice in every action and deed done. As explained in the letter An-Nisaa (4): 58): "Verily, Allah tells you to deliver the mandate to those who are entitled to receive it, and (to ask you) what if you establish a law among men so that you determine it fairly. Indeed, Allah gives you the best teaching. Verily Allah is Hearing and Seeing. " It is so important to act justly or uphold justice, so God warns those who believe that it is not because of hatred towards a people so that it influences it in doing justice and punishing.

The meaning contained in the conception of Islamic justice is to put something in its place, to impose something according to one's bearing capacity, to give something that is his right with a balanced level. The principal principle of justice is described by Madjid Khadduri by grouping it into two categories, namely substantive and procedural aspects, each of which includes one different aspect and justice. Substantive aspects in the form of elements of justice in the substance of the Shari'a (substantive justice), while procedural aspects in the form of elements of justice in procedural law that is implemented (procedural justice).

When procedural rules are ignored or applied incorrectly, procedural injustices arise. The substantive justice is an internal aspect and a law in which all actions that are obligatory must be fair (because of the word of God) and that which are unlawful are definitely unjust (because revelation is not possible to burden those who believe in wrongdoing). The application of procedural justice in Islam was raised by Ali ibn Abi Talib during the case before the Shuraih judge by reprimanding the judge as follows:

1) Be equal (the parties) enter them into the assembly, do not take precedence.

2) Let them sit before the judge.

3) Let the judge deal with them with the same attitude.

4) Let their statements be heard and cared for.

5) When imposing the law both must listen.

Imam Ali said that the principle of justice is a significant principle in maintaining the balance of society and getting public attention. Its application can guarantee the benefit of society and bring peace to their souls. Conversely oppression, tyranny, and discrimination will not be able to bring peace and happiness.

As for the prosecutor's duty as a researcher of investigating the results of narcotics crimes, especially against abuser cases, based on Law Number 35 of 2009 concerning narcotics the indictment is adjusted to the purpose of making the Act. The public prosecutor must be fair and extra careful because the abuser is a criminal case where the defendant is guaranteed a law to be 
rehabilitated (Article 4c). Abuse cases which by Law Number 35 Year 2009 concerning narcotics are decriminalized (acts which initially considered criminal, then considered as normal behavior). This means that the defendant was initially threatened with criminal offenses (Article 127). Forced efforts in the form of rehabilitation (Article 13 PP 25/2011), sanctions in the form of rehabilitation punishment (Article 103/1).

Decriminalization of narcotics abusers is indeed difficult to understand by the community and law enforcement because it is not well socialized and not taught in law schools in Indonesia. That is because only criminal justice systems are taught. As a result, when Law Number 35 of 2009 embraced the rehabilitation justice system by decriminalizing drug abuse, many people and law enforcers stuttered because their mindset was still a criminal justice system. Cases of abusers are still looking for ways to be detained and sentenced to prison until now even though the Narcotics Act has been running for 10 years.

In the future the task of prosecutors is tougher, namely: Building a single indictment in accordance with the mandate of the Narcotics Act, building synergy with investigators to unite the steps so that the abuser gets a rehabilitation sentence from the judge who adjudicates despite being charged with a criminal threat. Furthermore, the prosecutor is also tasked with ensuring the abuser gets rehabilitation to recover from addiction in order to carry out his social obligations. In addition, the prosecutor also coordinates with relevant agencies that carry out the rehabilitation function as a compulsory rehabilitation site from law enforcement sources.

If compulsory rehabilitation from law enforcement sources is carried out well, rehabilitation will flourish compulsory rehabilitation according to Article 55 of the Narcotics Law and PP 25 of 2011 concerning Obligatory Reporting Addicts. And furthermore, it is very possible to grow an "independent" rehabilitation movement by parents/families whose children become abusers without fear anymore dealing with law enforcement because of clear forced efforts and punishment in the form of rehabilitation.

To follow up on the command of Law No. 35 of 2009 concerning Narcotics, a joint regulation has been made between seven state institutions regarding the technical implementation of rehabilitation of narcotics abusers. The regulation was signed by the Chief Justice of the Supreme Court, the Minister of Law and Human Rights, the Minister of Health, the Minister of Social Affairs, the Attorney General, the Head of the Indonesian National Police, the Head of the National Narcotics Agency. The regulation was set on March 11, 2014. If you look at the time span between Law No. 35 of 2009 concerning Narcotics made in 2009 and the joint regulations of the seven state institutions regarding the implementation of rehabilitation techniques that were made new in 2014, then the question big is how the technical implementation of the rehabilitation before the emergence of a joint regulation of seven state institutions, or the more fundamental question is whether so far law enforcement officials have carried out the mandate contained in Article 54 of Law No.35 Year 2009. Because so far the tendency of law enforcement officers in handling cases of narcotics abuse is to impose criminal sanctions alone without imposing rehabilitation sanctions, of course this is the opposite of what is contained and listed in Article 54 of Law No.35 Year 2009.

Based on the above discussion, the Reconstruction of Criminal Sanctions Policy and Actions in Law Enforcement for the Narcotics Victims Act in Realizing Religious Justice is as follows:

1) Accelerating the revision of Law Number 35 Year 2009 concerning Narcotics which has been included in the list of prolegnas by accommodating various improvements to the Narcotics Law deficiencies as outlined above. 
2) Accelerating alternative development programs (alternative development) as agricultural substitution of sources of narcotics raw materials as well as rejecting all actions that seek to legalize narcotics in Indonesia;

3) Mapping of sea and land border areas which are categorized as prone to narcotics illicit trade transactions and enhancing integrated surveillance and security systems with other stakeholders at land and sea border crossings, container ports, small ports, and airports;

4) Prevention of the circulation of new types of narcotics and new types of narcotics precursors (new psychoactive substances) through a more comprehensive set of legal norms in the form of annual evaluations and renewal of laws and regulations related to narcotics types, as well as firm action on non-pharmaceutical industries which are categorized as deviating narcotics precursor production. new;

5) Preparation of a sustainable development program for a generation of Indonesian narcotics-free gold through a special curriculum design to prevent narcotics abuse from elementary, secondary, and tertiary level students requires strengthening coordination with the National Narcotics Agency to carry out periodic inherent supervision;

6) Institutional improvement of BNN in the form of (a) acceleration of the establishment of National Narcotics Agency institutions at the district / city level by prioritizing regency / city priorities that have airport and port facilities, border areas, high circulation and narcotics users, as well as increasing achievement of measurable targets of eradication programs narcotics; (b) optimizing adequate budget support, whether sourced from the state budget or regional budget to fulfill the support for infrastructure facilities needed to eradicate narcotics crime; and (c) strengthening the institutional legal status of BNN which is equivalent to Forkompinda in the regions so that it can have an impact on strengthening the budget and optimizing coordination with stakeholders;

7) Involvement of regional governments and communities to prevent and eradicate narcotics crimes by forming task force units (task force) from the provincial to village level;

8) Improvement of the supervision system of narcotics distribution in prisons by considering (1) the establishment of special Narcotics prisons; (2) increase in the number of prison staff; and (3) carrying out periodic unannounced inspections;

9) Evaluate and improve the mentality of law enforcement officials in combating narcotics crime by considering: (i) competence, quantity and quality of law enforcement officers; (ii) strengthening the character of law enforcement officers; (iii) welfare of law enforcement officers; and (iv) use of proceeds from money laundering crimes originating from narcotics crime as an alternative funding support for BNN programs and activities that are not budgeted by the APBN.

10)Rehabilitation Programs through (a) increasing the budget of rehabilitation center infrastructure facilities that are allocated, both in the APBN and APBD; (b) adoption of a religious approach at the government-owned narcotics rehabilitation center; and (c) the establishment of an interagency coordination forum that conducts rehabilitation for narcotics abusers.

We need to know that in fact they really need medical and social rehabilitation to restore their condition. They are in prison in a position of drug dependence and all means will be done to 
obtain drugs. During this time they did not get therapy at the Penitentiary to reduce drug dependence so that the condition is still sick. Coupled with the conditions of prisons in Indonesia, most of which are already over capacity. This condition can aggravate the situation, some Prisoners who were not involved in the Narcotics network may become dealers. Efforts to make a sudden inspection of narcotics users at the Penitentiary will only stop this activity temporarily. The root of the problem is precisely in the presence of a substantial Narcotics demand and the supply so that transactions occur.

Setting up rehabilitation centers especially for narcotics offenders is also the right solution. They need a process of healing from drug addiction. Just imprisonment is not the right solution for this problem, but also holding medical treatment will succeed. It's no secret that many drug users in Penitentiary but still drug dependence. This is because they are only physically detained but the disease has not yet healed. They need treatment that has not been maximally obtained. The construction of a Penitentiary-based rehabilitation center is also very necessary so that the handling of Narcotics actors can be handled appropriately and they also get the full justice, namely religious justice.

\section{CONSLUSION}

The Criminal Sanction Policy and Actions in Enforcing the Law on the Narcotics Control System in Realizing Religious Justice can be used as an alternative sanction in the reformulation of drug addiction. Just imprisonment is not the right solution to this problem, arrest but also do a medical therapist then it will work. It's no secret that many drug users in prison but still dependence of this drug. This is because they are only physically detained but the disease has not yet healed. They need medical treatment that is not maximally obtained.

\section{BIBLIOGRAPHY}

Andri winjaya laksana, Arpangi, JURIDICAL ANALYSIS OF SANCTIONS TRESPASSER AGAINST NARCOTIC'S VICTIM BASED ON UTILITARIANISM JUSTICE VALUES, Jurnal Pembaharuan Hukum, Volume VI No.1 Januari-April,

Maydiya Restacendi Nur'artavia, KARAKTERISTIK PELAJAR PENYALAHGUNA NAPZA DAN JENIS NAPZA YANG DIGUNAKAN DI KOTA SURABAYA, The Indonesian Journal of Public Health, Vol. 12 No. 1, Juli 2017

Samosir, Djisman, 1992, FUNGSI PIDANA PENJARA DALAM SISTEM PEMIDANAAN DI INDONESIA, Bina Cipta, Bandung; 1992, P.67. 